\title{
Compositional analysis of bacterial communities in seawater, sediment, and sponges in the Misool coral reef system, Indonesia
}

\author{
Daniel Francis Richard Cleary ${ }^{1}$ - Ana Rita Moura Polónia ${ }^{1}$ - Leontine E. Becking ${ }^{2,3,4}$. \\ Nicole Joy de Voogd ${ }^{2} \cdot$ Purwanto $^{5} \cdot$ Helder Gomes $^{1} \cdot$ Newton Carlos Marcial Gomes $^{1}$
}

Received: 31 January 2016 / Revised: 13 March 2017 / Accepted: 3 April 2017 /Published online: 23 April 2017

(C) Senckenberg Gesellschaft für Naturforschung and Springer-Verlag Berlin Heidelberg 2017

\begin{abstract}
Sponge species have been deemed high microbial abundance (HMA) or low microbial abundance (LMA) based on the composition and abundance of their microbial symbionts. In the present study, we evaluated the richness and composition of bacterial communities associated with one HMA sponge (Xestospongia testudinaria; Demospongiae: Haplosclerida: Petrosiidae), one LMA sponge (Stylissa carteri; Demospongiae: Scopalinida - Scopalinidae), and one sponge with a hitherto unknown microbial community (Aaptos suberitoides; Demospongiae: Suberitida: Suberitidae) inhabiting the Misool coral reef system in the West Papua province of Indonesia. The bacterial communities of these sponge species were also compared with seawater and sediment bacterial communities from the same coastal coral reef habitat. Using a $16 \mathrm{~S}$ rRNA gene barcoded pyrosequencing
\end{abstract}

Communicated by P. Martinez Arbizu

Electronic supplementary material The online version of this article (doi:10.1007/s12526-017-0697-0) contains supplementary material, which is available to authorized users.

Daniel Francis Richard Cleary

cleary@ua.pt; dfrcleary@gmail.com

1 Department of Biology, CESAM, Universidade de Aveiro, Campus Universitário de Santiago, 3810-193 Aveiro, Portugal

2 Marine Biodiversity, Naturalis Biodiversity Center, Darwinweg 2, 2333 CR Leiden, The Netherlands

3 Marine Animal Ecology, Wageningen UR, P.O. Box 338, 6700 AH Wageningen, The Netherlands

4 Department of Environmental Science, Policy, and Management, University of California Berkeley, 130 Mulford Hall, Berkeley, CA 94720-3114, USA

5 Department of Fisheries and Marine Science, University of Diponegoro, Jalan Prof. H. Soedarto, Semarang, Indonesia approach, we showed that the most abundant phylum overall was Proteobacteria. The biotope (sponge species, sediment or seawater) explained almost $84 \%$ of the variation in bacterial composition with highly significant differences in composition among biotopes and a clear separation between bacterial communities from seawater and S. carteri; X. testudinaria and A. suberitoides and sediment. The Chloroflexi classes SAR202 and Anaerolineae were most abundant in A. suberitoides and X. testudinaria and both of these species shared several OTUs that were largely absent in the remaining biotopes. This suggests that $A$. suberitoides is a HMA sponge. Although similar, the bacterial communities of $S$. carteri and seawater were compositionally distinct. These results confirm compositional differences between sponge and non-sponge biotopes and between HMA and LMA sponges.

Keywords Aaptos suberitoides - Microbial abundance . Stylissa Carteri $\cdot 16 \mathrm{~S}$ rRNA gene, Xestospongia testudinaria

\section{Introduction}

Coral reefs are highly diverse, but also globally threatened ecosystems. Local perturbations including overfishing and pollution combined with global phenomena such as coral bleaching have had a disastrous effect on coral reefs (Bruno and Selig 2007; De'ath et al. 2012; Pandolfi et al. 2003). Coral cover in certain reefs has virtually disappeared leading to the loss of important ecosystem services such as renewable resources (e.g., fisheries), protection against erosion, and nutrient cycling (Moberg and Folke 1999). The loss of coral cover also leads to the loss of dependent species such as numerous fish species and shifts in composition to reefs dominated by non-coral taxa such as algae or sponges (Bellwood et al. 2004). 
Sponges (Phylum Porifera) are ancient metazoans (van Soest et al. 2012) with a fossil record dating back to the Precambrian (Li et al. 1998). The majority of the 8826 valid living species belong to the class Demospongia (demosponges) (Borchiellini et al. 2001; van Soest et al. 2012). The remaining species represent the classes Hexactinellida (glass sponges), Calcarea (calcareous sponges), and Homoscleromorpha. They have successfully colonised a range of aquatic environments from tropical to polar, shallow to deep water, and marine and freshwater (Rützler 2004). They are also structurally important components of coral reefs where they provide shelter for numerous organisms and contribute to reef regeneration and stabilisation (de Voogd et al. 2006). In addition to the above, they are one of the most important marine sources of promising pharmaceutical compounds (Faulkner 2002; Taylor et al. 2007).

Sponges are known to host large communities of microbial symbionts of known ecological and biotechnological importance (Freeman and Thacker 2011). They are also unique and, depending on the species, highly selective environments for microbes (Cleary et al. 2013, 2015; Freeman and Thacker 2011; Hentschel et al. 2006). The prokaryote metabolism requires nitrogen and carbon; sponges produce both, often in ample quantities, by releasing ammonia, as an end product of their metabolism, and carbohydrates and amino acids, as a consequence of phagocytosis (Hentschel et al. 2006). Microbial symbionts, in turn, provide sponges with important nutrients (Flatt et al. 2005), process metabolic waste, improve host defence and stabilise the host skeleton (Hentschel et al. 2006). Some sponge species also house specific microbial communities that may be similar over large geographical distances (Flatt et al. 2005).

Microbes inhabit the mesophyll-matrix of most desmosponges (Hentschel et al. 2003). The abundance and composition of sponge-associated microorganisms can vary greatly among sponge species, including those inhabiting the same habitat (Cleary et al. 2013, 2015; de Voogd et al. 2015). High microbial abundance (HMA) sponges can contain around $10^{10}$ bacterial cells $g^{-1}$ wet weight of sponge ( 2 to 4 orders of magnitude higher than concentrations in sea water) (Hentschel et al. 2006), while low microbial abundance (LMA) sponges contain around $10^{6}$ cells g $^{-1}$ (similar to concentrations in sea water) (Kamke et al. 2010).

HMA sponges also tend to host more diverse bacterial communities including Proteobacteria, Chloroflexi, Acidobacteria, and Actinobacteria (Gloeckner et al. 2014). Previously, the determination of HMA or LMA status was made on the basis of electron microscopy and morphotype with HMA sponges containing more densely packed microbial communities and smaller canals and choanocyte chambers compared to LMA sponges (Schlappy et al. 2010; Vacelet and Donadey 1977). Gloeckner et al. (2014), however, showed that electron microscopy was not always sufficient to determine HMA or LMA status and that sponges existed with intermediate microbial abundances. They, therefore, suggested combining electron microscopy with 16S rRNA gene sequence data. The latter may in fact be a better determinant given the sometimes ambiguous results obtained by Gloeckner et al. (2014).

In the present study, we compared the richness and composition of bacteria in three sponge species inhabiting open coastal habitat, sediment and seawater from a coral reef system in South East Misool, Raja Ampat, West Papua, Indonesia. Located on the northwestern tip of Papua, eastern Indonesia, the Raja Ampat region consists of nearly 1500 islands and is considered an area with a global priority for conservation (Roberts et al. 2002). It is among the most biodiverse regions on Earth possessing over $75 \%$ of the world's coral species and almost a thousand species of reef fish (e.g., Allen 2008; Allen and Erdmann 2009; Mangubhai et al. 2012). The reefs and mangrove systems in SE Misool encompass an area of outstanding marine biological diversity (e.g., Allen 2008; Becking et al. 2014; Mangubhai et al. 2012) and harbour some of the most pristine reefs in Indonesia (Grantham et al. 2013; Mangubhai et al. 2012). As a result, a Marine Protected Area of 343,200 ha was established in SE Misool in 2009 (KKPD Misool Timur-Selatan).

We mainly focused our analysis on bacterial communities of the LMA sponge Stylissa carteri (Dendy, 1889) and the HMA giant barrel sponge Xestospongia testudinaria (Lamarck, 1815) in addition to the sponge Aaptos suberitoides (Brøndsted, 1934). Stylissa carteri (Fig. 1) is a common Indo-Pacific bright orange flabelliform sponge that occurs from the Red Sea to Taiwan (de Voogd and Cleary 2008; Giles et al. 2015). Numerous bromopyrolle alkaloids with promising antiviral, antibacterial, and anticancer properties have been isolated from species belonging to the genus Stylissa (Ebada et al. 2015; Rohde et al. 2012).

Xestospongia testudinaria (Fig. 2) is one of the largest known sponges. It usually has an erect and barrel-shaped

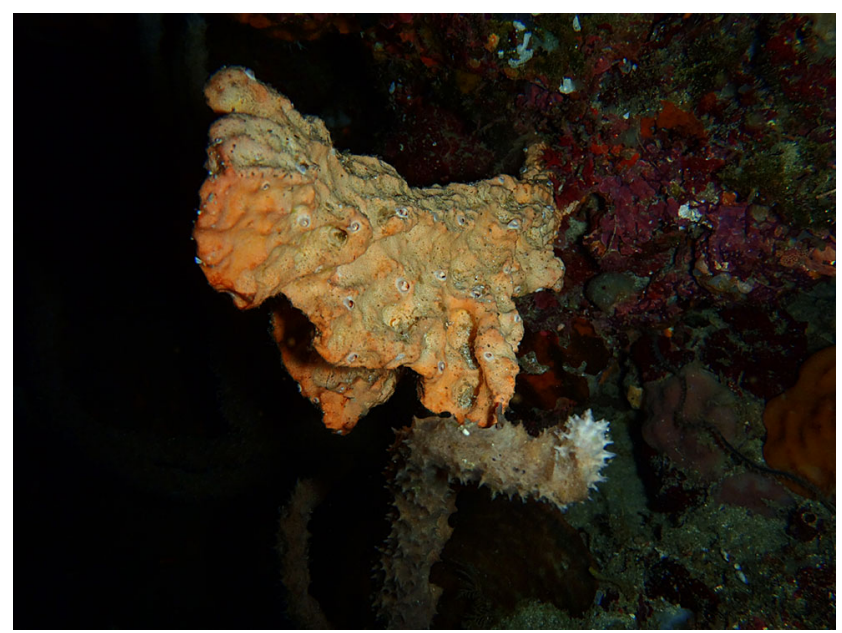

Fig. 1 Photograph of Stylissa carteri (Dendy, 1889) taken by LE Becking in Misool 
structure that can measure up to $2.4 \mathrm{~m}$ in height and width. The surface texture varies from smooth to highly digitate or lamellate (Swierts et al. 2013). It also has an incredible life span that may exceed 2000 years (McMurray et al. 2008). It can be found from the Red Sea to the Great Barrier Reef (de Voogd et al. 2006; Moitinho-Silva et al. 2014; Pham et al. 1999) and can be locally abundant in coral reefs, usually at depths greater than $10 \mathrm{~m}$, but can also occur at shallower depths in certain reefs (de Voogd and Cleary 2009; Huang et al. 2016; Swierts et al. 2013). Xestospongia species are among the richest sources of pharmacologically active chemical compounds isolated from marine organisms. Xestospongia testudinaria has been shown to produce compounds with potential applications in the treatment of obesity, diabetes mellitus, arteriosclerosis, and Alzheimer's disease (Akiyama et al. 2013; Liang et al. 2014).

Aaptos suberitoides (Fig. 3) occurs in shallow coral reefs in the coral triangle (de Voogd and Cleary 2008). It forms thick irregular lobate masses that can occupy large parts of the reef. Its exterior is dark brown, but the interior is canary yellow and stains dark brown after preservation. It has been shown to produce compounds with antitumor, antimicrobial, and antiviral activity (Aoki et al. 2006; Jin et al. 2011; Larghi et al. 2008; Liu et al. 2012; Pham et al. 2013; Tsukamoto et al. 2010).

The main objectives of this study were to identify the most abundant higher bacterial taxa, compare bacterial richness and composition among sponge hosts and nonsponge biotopes (sediment and seawater), and identify dominant bacterial OTUs and their closest known relatives.

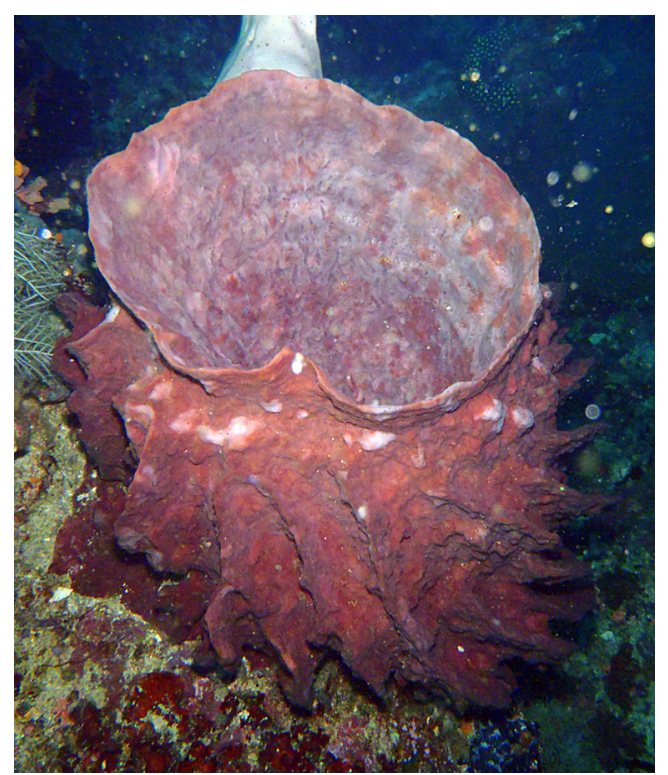

Fig. 2 Photograph of Xestospongia testudinaria (Lamarck, 1815) taken by LE Becking in Misool

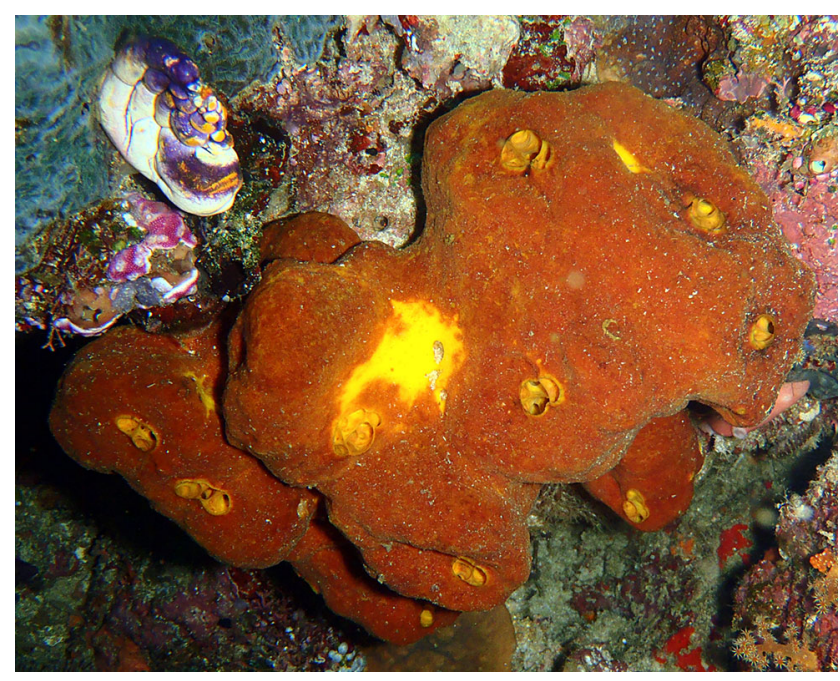

Fig. 3 Photograph of Aaptos suberitoides (Brøndsted, 1934) taken by LE Becking in Misool

\section{Material and methods}

\section{Study site}

Samples of S. carteri, A. suberitoides, and X. testudinaria were collected by snorkelling and SCUBA diving from the 13th to the 18th of September 2013 in Southeast Misool, Raja Ampat region, West Papua province in Indonesia (Fig. 4). SE Misool is part of a marine protected area of 343,200 ha established in 2009 (KKPD Misool Timur-Selatan). The equatorial location of Misool means that the main seasonal influence is driven by monsoons (Prentice and Hope 2007). Misool is most influenced by the southeast monsoon from May to October, which is characterised by cooler sea surface temperatures (SSTs), persistent winds and strong ocean swell. The annual rainfall in Papua averages $2500-4500 \mathrm{~mm}$ with interannual variability in rainfall due to the El Niño Southern Oscillation (ENSO; Prentice and Hope 2007). There are seasonal differences in SSTs with an average SST of $29.0^{\circ} \mathrm{C}$, ranging from 19.3 to $36.0^{\circ} \mathrm{C}$ (Mangubhai et al. 2012).

\section{Data collection}

In the study area, small fragments of the interior and exterior parts of the sponges $S$. carteri (Demospongiae: Scopalinida Scopalinidae), A. suberitoides (Demospongiae: Suberitida: Suberitidae), and X. testudinaria (Demospongiae: Haplosclerida: Petrosiidae) were sampled in order to sample, as much as possible, the whole bacterial community. Specimens were collected from shallow water reefs (depth range: 7-17 m) and identified in the field. Voucher specimens of sponges have been deposited in the sponge collection of Naturalis Biodiversity Center, the Netherlands (RMNH Porifera). Sediment samples were taken using mini cores; this consisted of sampling the top $5 \mathrm{~cm}$ of sediment with a plastic disposable syringe from which 
Fig. 4 Map of study area showing the location of the study sites

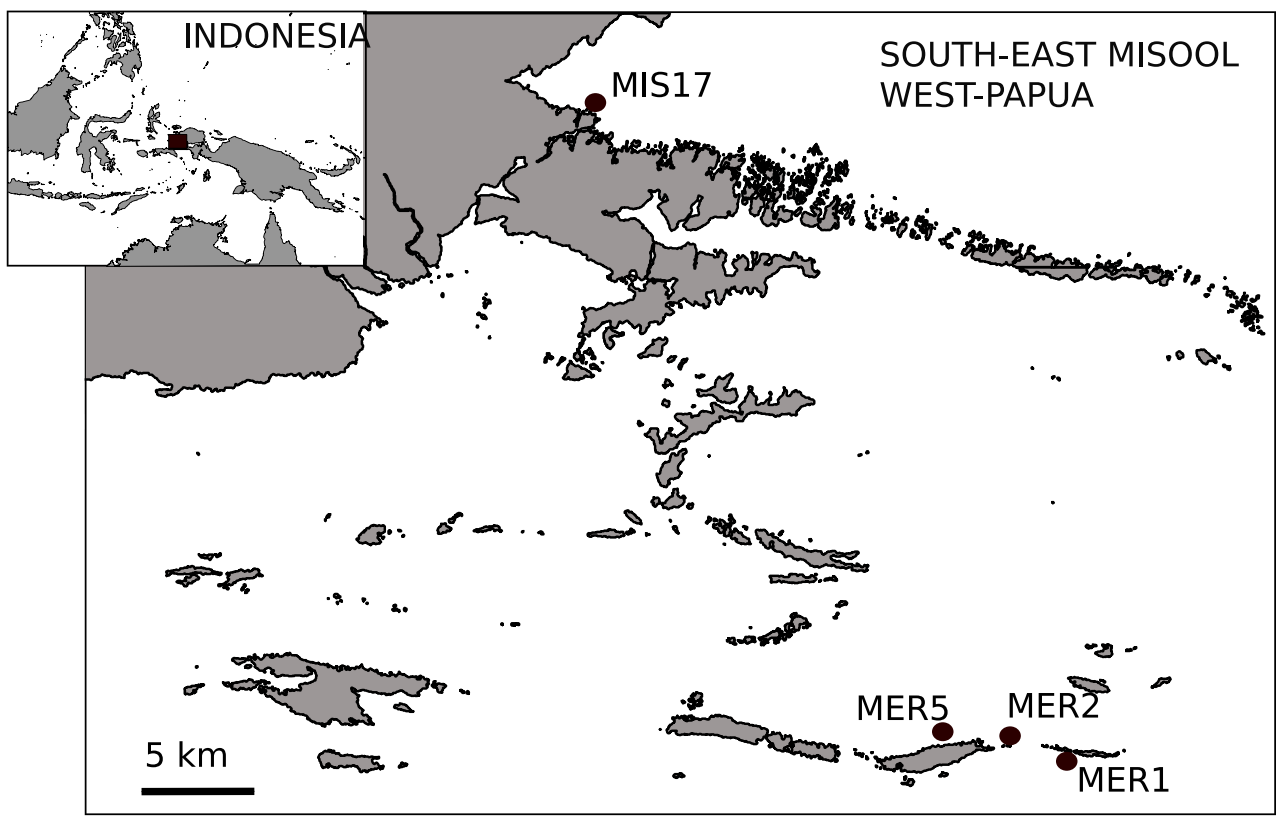

the end had been cut in order to facilitate sampling (Capone et al. 1992). Seawater samples were collected by filtering $1 \mathrm{~L}$ of seawater through a Millipore ${ }^{\circ}$ White Isopore Membrane Filter (GTTP04700, $47 \mathrm{~mm}$ diameter, $0.22 \mu \mathrm{m}$ pore size). Samples were stored in $96 \% \mathrm{EtOH}$. After sampling, tubes containing the samples were frozen or carried in ice during travel between fieldwork lodging and the Netherlands and Portugal, where the samples were stored at $-80 .{ }^{\circ} \mathrm{C}$ until processing. For the present study, three samples each of the sponges $S$. carteri, A. suberitoides, and $X$. testudinaria, sediment and seawater were assessed for bacterial community analysis.

\section{DNA extraction and pyrosequencing}

\section{Total community-DNA extraction and $16 \mathrm{~S}$ rRNA gene barcoded-pyrosequencing}

We isolated PCR-ready total community DNA (TC-DNA) from sediment, seawater, and sponge samples using the FastDNA® SPIN Kit (MP Biomedicals) following the manufacturer's instructions. Briefly, we prepared sediment samples by centrifuging each one for $30 \mathrm{~min}$ at $4400 \mathrm{rpm}$ and $4{ }^{\circ} \mathrm{C}$; the membrane filter (seawater sample) and sponge samples were each cut into small pieces. The whole membrane filter and $500 \mathrm{mg}$ of sediment or sponge were transferred to Lysing Matrix E tubes containing a mixture of ceramic and silica particles. The microbial cell lysis was performed in the FastPrep ${ }^{\circledR}$ Instrument (Q Biogene) for $80 \mathrm{~s}$ at speed 6.0. Extracted DNA was eluted into DNase/PyrogenFree Water to a final volume of $50 \mu \mathrm{L}$ and stored at $-20^{\circ} \mathrm{C}$ until use. Prior to pyrosequencing, the amplicons of the bacterial $16 \mathrm{~S}$ rRNA gene were obtained using bacterial specific primers $27 \mathrm{~F}$ and 1494R (Gomes et al. 2001). After a denaturation step at $94{ }^{\circ} \mathrm{C}$ for $5 \mathrm{~min}, 25$ thermal cycles of $45 \mathrm{~s}$ at $94{ }^{\circ} \mathrm{C}, 45 \mathrm{~s}$ at
$56{ }^{\circ} \mathrm{C}$, and $1: 30 \mathrm{~min}$ at $72{ }^{\circ} \mathrm{C}$ were carried out, followed by an extension step at $72{ }^{\circ} \mathrm{C}$ for $10 \mathrm{~min}$. With the amplicons of the bacterial 16S rRNA gene as template, the V3V4 region was amplified using barcoded fusion primers with the Roche-454 A Titanium sequencing adapters, a six-base barcode sequence, forward V3 primer 5'-ACTCCTACGGGAGGCAG-3' (Yu et al. 2005), and V4 reverse degenerate primer 5' TACNVRRGTHTCTAATYC-3' (Vaz-Moreira et al. 2011).

Sequence analyses were performed using previously described methods (Cleary et al. 2015; de Voogd et al. 2015). Briefly, in QIIME, fasta and qual files were used as input for the split_libraries.py script. OTUs were selected using UPARSE with usearch7 (Edgar 2013). Chimera checking was performed using the UCHIME algorithm, which is the fastest and most sensitive chimera checking algorithm currently available (Edgar et al. 2011). OTU clustering was performed using the cluster_otus command (cut-off threshold at 97\%). (see Online Resource 1 for a detailed description). Closely related organisms of numerically abundant OTUs ( $\geq 200$ sequences) were identified using the NCBI Basic Local Alignment Search Tool (BLAST) command line "blastn" tool with the -db argument set to nt (Zhang et al. 2000). The DNA sequences generated in this study can be downloaded from the NCBI SRA: SRP069346.

\section{Phylogenetic tree}

Selected 16S rRNA gene sequences of the most dominant OTUs and representative cultured and uncultured closest relatives in GenBank [http://www.ncbi.nlm.nih.gov/] were aligned using ClustalW and a phylogenetic analysis conducted using MEGA 6 software (http://www. megasoftware.net/; last checked 201407 09) (Tamura et al. 2013). A phylogenetic tree was constructed using the 
neighbour-joining method and evolutionary distances were computed using the maximum composite likelihood method with a discrete Gamma distribution. In the results, we present a bootstrap consensus tree based on 1000 replicates. The bootstrap value is shown next to each branch when this exceeds $49 \%$. This value represents the percentage of replicate trees in which the associated taxa clustered together.
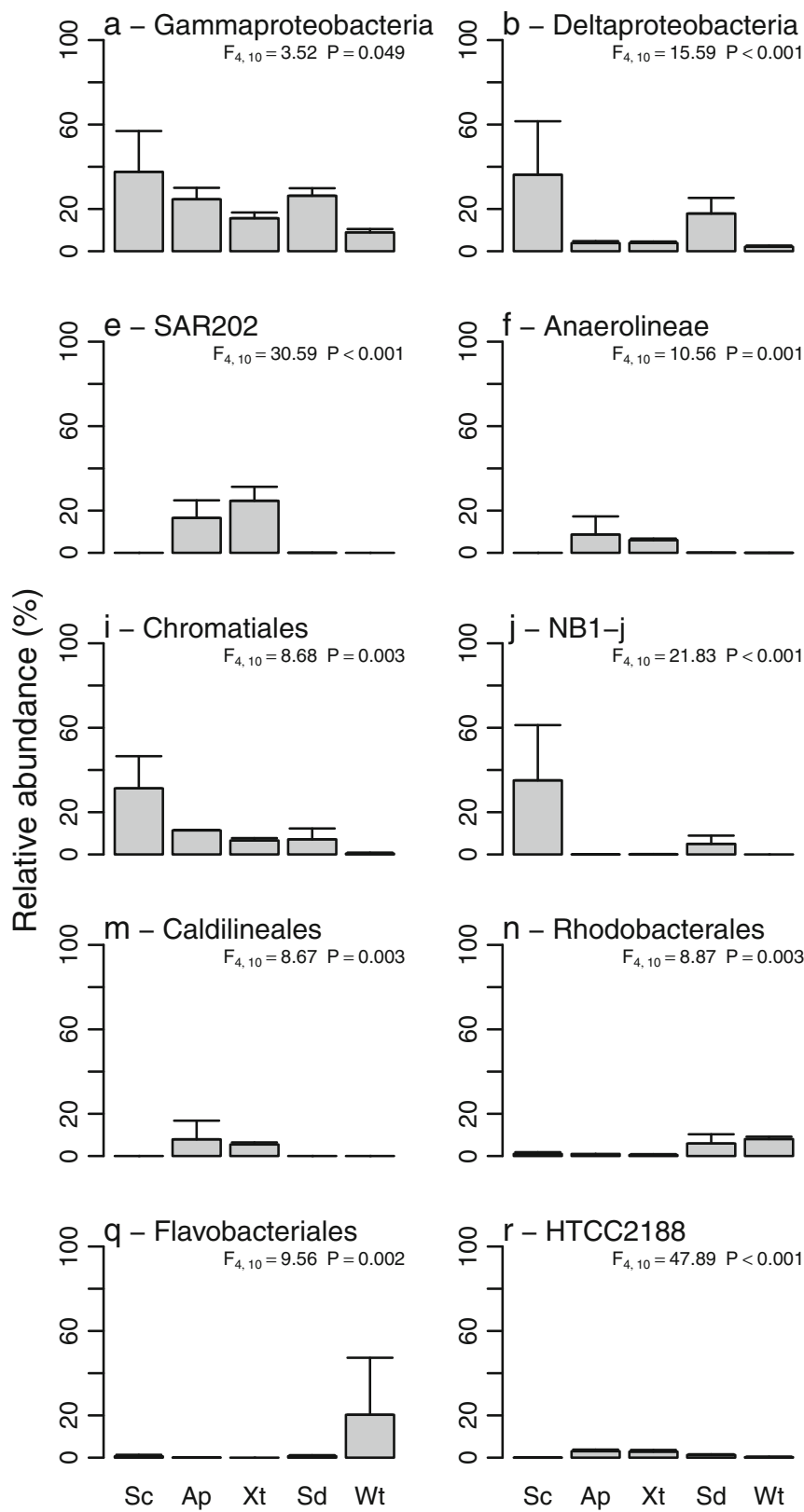

Fig. 5 Mean (error bars represent a single standard deviation) relative abundance of the most abundant bacterial classes and orders and the most abundant OTU (dominant OTU) for samples from $S$. carteri $(\mathrm{Sc})$, A. suberitoides (Ap), X. testudinaria (Xt), sediment (Sd), and seawater (Wt). Note that the abundance of the dominant OTU refers to the abundance of the most abundant OTU per sample and thus not the most abundant OTU overall. a Gammaproteobacteria, b Deltaproteobacteria, c

\section{Statistical analysis}

A table containing the presence and abundance of all OTUs per sample was imported into $\mathrm{R}$ using the read.table() function. Plant organelles, mitochondria and sequences not classified as Bacteria (e.g., Archaea) were removed prior to statistical analysis.
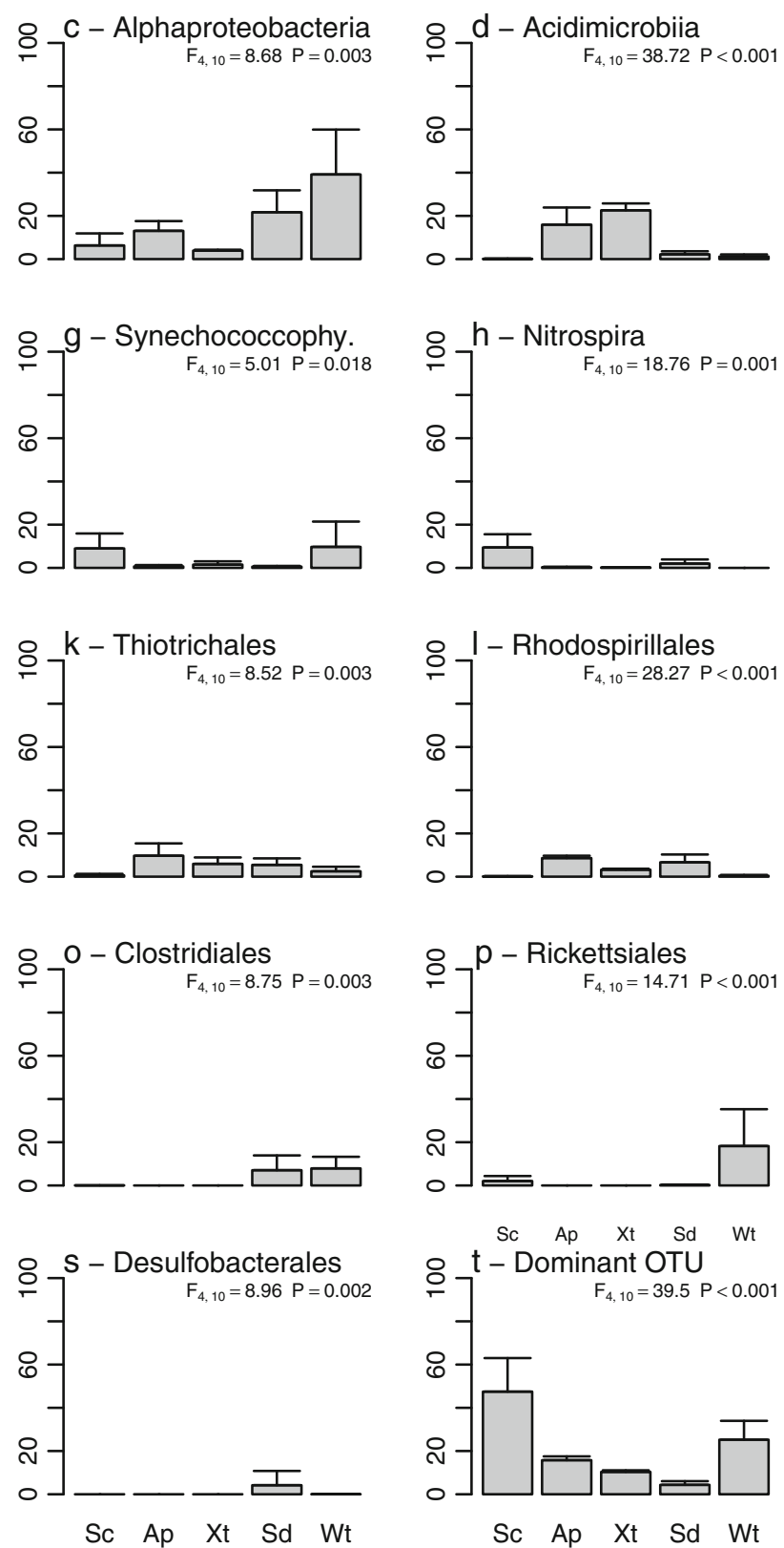

Alphaproteobacteria, d Acidimicrobiia, e SAR202, f Anaerolineae, g Synechococcophysidae, h Nitrospira, i Chromatiales, j NB1 - j, k Thiotrichales, 1 Rhodospirillales, $\mathrm{m}$ Caldilineales, $\mathrm{n}$ Rhodobacterales, o Clostridiales, p Rickettsiales, q Flavobacteriales, r HTCC2188, s Desulfobacterales, and the dominant OTU. Results of the GLM analyses for each taxon are presented in the top right of each subfigure 


\section{Richness and higher taxon abundance}

We used a self-written function in $\mathrm{R}$ (Gomes et al. 2010) to estimate rarefied OTU richness for each sample. Care, however, should be taken in the interpretation of richness estimates based on sequence data given the prevalence of sequencing errors (Edgar 2013). We tested for significant differences in the relative abundance of selected higher taxon groups (classes and orders) among habitats with an analysis of deviance using the $\operatorname{glm}()$ function in R. As data were proportional, we first applied a GLM with the family argument set to binomial. However, the ratio of residual deviance to residual degrees of freedom in the models substantially exceeded one so we set family to "quasibinomial". In the "quasibinomial" family, the dispersion parameter is not fixed at one so that it can model over-dispersion. Using the GLM model, we tested for significant variation among habitats using the anova() function in $\mathrm{R}$ with the F test, which is most appropriate when dispersion is estimated by moments as is the case with quasibinomial fits.

\section{Composition}

The OTU abundance matrix was $\log _{\mathrm{e}}(x+1)$ transformed (in order to normalise the distribution of the data), and a distance matrix was constructed using the Bray-Curtis index with the vegdist() function in the VEGAN package (Oksanen et al. 2009) in R. The Bray-Curtis index is one of the most frequently applied (dis)similarity indices used in ecology (Cleary 2003; Legendre and Gallagher 2001; Polónia et al. 2014). Variation in OTU composition among biotopes ( $S$. carteri, A. suberitoides, $X$. testudinaria, sediment, and seawater) was assessed with principal coordinates analysis (PCO) using the cmdscale() function in $\mathrm{R}$ with the Bray-Curtis distance matrix as input. Variation among biotopes was tested for significance using the adonis() function in VEGAN. In the adonis analysis, the BrayCurtis distance matrix of species composition was the response variable with the biotope as independent variable. The number of permutations was set at 999; all other arguments used the

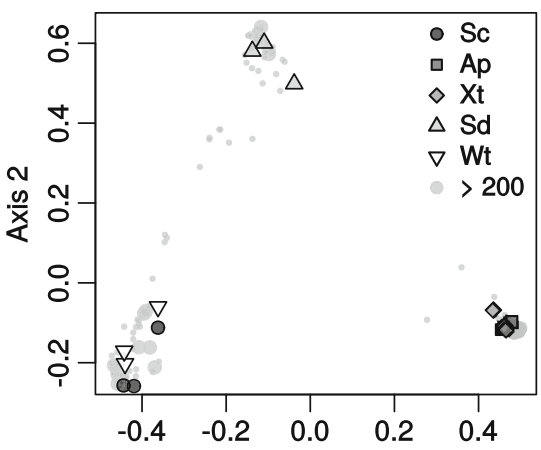

Fig. 6 Ordination showing the first two axes of the PCO analysis. a. Symbols represent samples from $S$. carteri (Sc), A. suberitoides (Ap), $X$. testudinaria $(\mathrm{Xt})$, sediment $(\mathrm{Sd})$, and seawater $(\mathrm{Wt})$. b. Ordination default values set in the function. Weighted averages scores were computed for OTUs on the first four PCO axes using the wascores() function in the vegan package. Detailed descriptions of the functions used here can be found in $\mathrm{R}$ (e.g.,?cmdscale) and online in reference manuals (http://cran.rproject.org/web/packages/vegan/index.html; 2015/05/29).

\section{Results}

The sequencing effort yielded 50,223 sequences, which were assigned to 3797 OTUs after quality control, OTU picking and removal of chimeras, chloroplasts, mitochondria, and sequences not assigned to the Bacteria domain. OTU richness was by far highest in the sediment biotope and lowest in $S$. carteri (Online Resource 2). The most abundant phylum overall was Proteobacteria where mean relative abundance ranged from $23.6 \pm 2.9 \%$ in $X$. testudinaria to $80.3 \pm 1.8 \%$ in $S$. carteri (Online Resource 3). Chloroflexi were most abundant in A. suberitoides $(30.5 \pm 10.6 \%)$ and $X$. testudinaria $(33.0 \pm 6.0 \%)$, but represented less than $1 \%$ of sequences in $S$. carteri, sediment, and seawater. The same held for Actinobacteria, which represented $16.0 \pm 7.8$ of $A$. suberitoides sequences and $22.7 \pm 3.2 \%$ of $X$. testudinaria sequences. The mean abundance of Actinobacteria in the other biotopes ranged from $0.1 \pm 0.1 \mathrm{in} S$. carteri to $2.4 \pm 1.5$ in sediment. Bacteroidetes were most abundant in sediment $(8.2 \pm 2.4)$ and seawater (20.8 \pm 26.6$)$ but represented less than $1 \%$ of sequences in all sponge biotopes. Although highly variable within biotope samples, Cyanobacteria abundance was highest in $S$. carteri $(9.0 \pm 6.9)$ and seawater $(9.9 \pm 11.9)$ and much lower in sediment $(1.5 \pm 0.1)$, A. suberitoides $(0.7 \pm 0.6)$, and $X$. testudinaria $(1.5 \pm 1.5)$.

\section{Higher taxon abundance}

In line with the phylum-level results, there were marked differences in the abundance of selected classes and orders

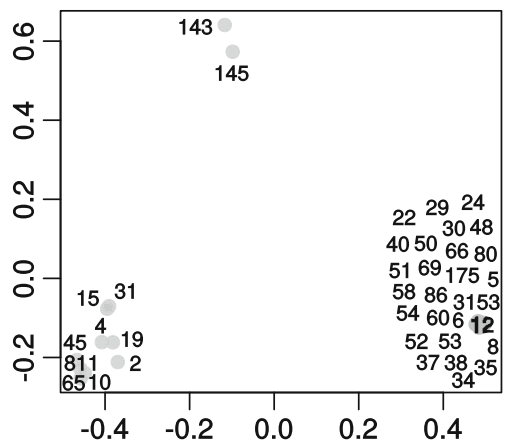

Axis 1

showing only the most abundant OTUs. Numbers represent dominant ( $\geq 200$ sequence reads) OTUs referred to in Table 1. Small circles represent OTUs $<200$ sequence reads 


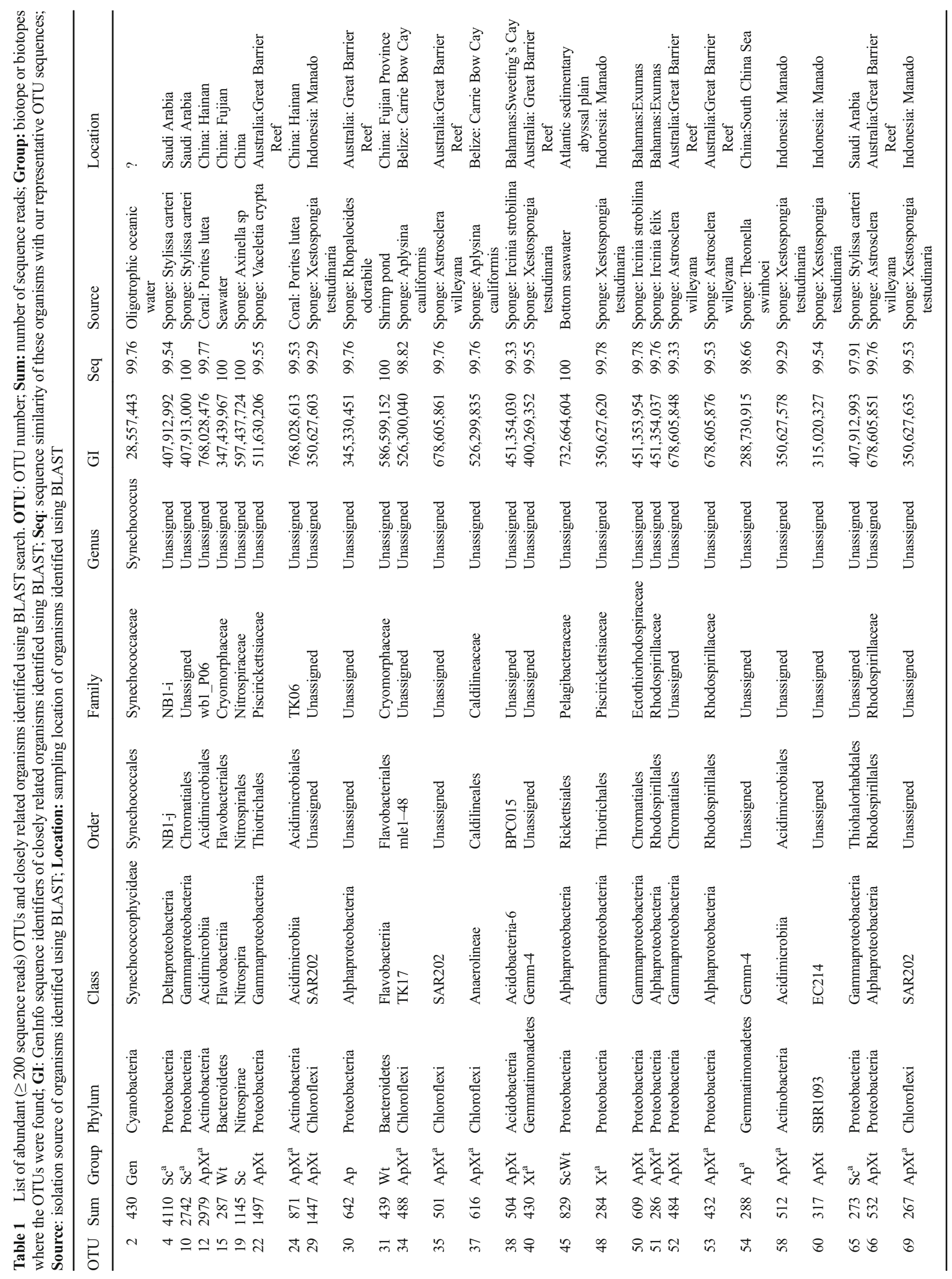




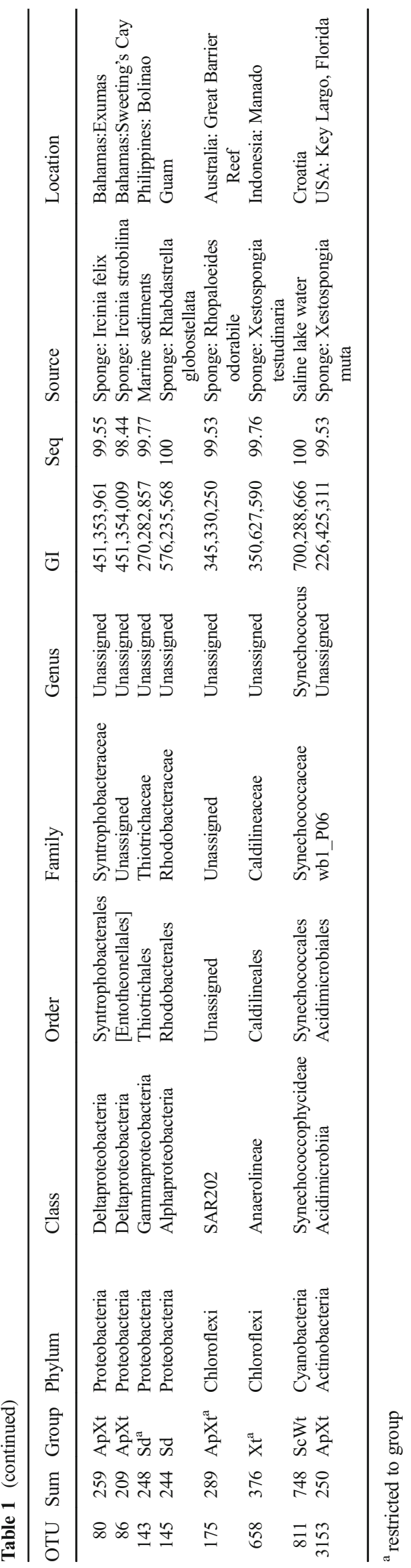

(Fig. 5). Sequences assigned to the Chloroflexi classes SAR202 and Anaerolineae and the order Caldilineales were largely restricted to A. suberitoides and $X$. testudinaria. The abundance of Gammaproteobacteria was greatest in S. carteri, largely due to the prevalence of OTUs assigned to the order Chromatiales. The class Deltaproteobacteria was most abundant in S. carteri and sediment, largely due to the order NB1 $-\mathrm{j}$ in both biotopes and Desulfobacterales in sediment. Dominance was by far greatest in $S$. carteri with a mean of $47.4 \% \pm 15.5$ of sequences assigned to the most abundant OTU. In contrast, dominance was lowest in sediment with a mean of only $4.4 \% \pm 1.7$ of sequences assigned to the most abundant OTU.

\section{Importance of biotopes in structuring composition}

There was a highly significant difference in bacterial composition among biotopes $\left(\mathrm{F}_{3,8}=13.07, P<0.001, \mathrm{R}^{2}=0.839\right)$. Variation among biotopes thus explained almost $84 \%$ of the variation in composition. In the PCO ordination of the first two axes (Fig. 6), there are three distinct clusters, namely: a cluster of samples from A. suberitoides and X. testudinaria, a cluster of samples from sediment and a cluster of samples from $S$. carteri and seawater. The main axis (axis 1) separated samples of $A$. suberitoides and $X$. testudinaria from samples of $S$. carteri and seawater. The second axis (axis 2 ) separated all these samples from samples of sediment. For the purposes of this study, a total of 36 OTUs were considered abundant $(\geq$ 200 sequences). Only two abundant OTUs were associated with sediment. OTU-143 was restricted to sediment samples and closely related ( $>99 \%$ sequence similarity) to an organism obtained from marine sediment in the Philippines (Table 1). OTU-145 was mainly found in sediment in this study, but had $100 \%$ sequence similarity with an organism previously obtained from the sponge Rhabdastrella globostellata in Guam. A number of OTUs were mainly found in seawater and $S$. carteri. This included OTU-45 that was related to an organism previously found in bottom seawater of the Atlantic abyss and OTU-811 that was related to an organism previously found in Croatian marine lake water. Most of the abundant OTUs were associated with $A$. suberitoides and $X$. testudinaria and were often absent in other biotopes. This mainly included OTUs previously isolated from sponges and corals (e.g., OTUs 12 and 24). Most of these OTUs were shared between both sponge species although one (OTU-54) was restricted to $A$. suberitoides and three to $X$. testudinaria (OTUs 45, 48 and 658). OTUs 40 (restricted to $X$. testudinaria) and 54 (restricted to A. suberitoides) were both assigned to the phylum Gemmatimonadetes.

The third PCO axis mainly separated $S$. carteri samples from seawater samples. OTUs associated with and restricted to $S$. carteri included OTUs 4,10 , and 65 all of which were related to organisms previously obtained from $S$. carteri in the 

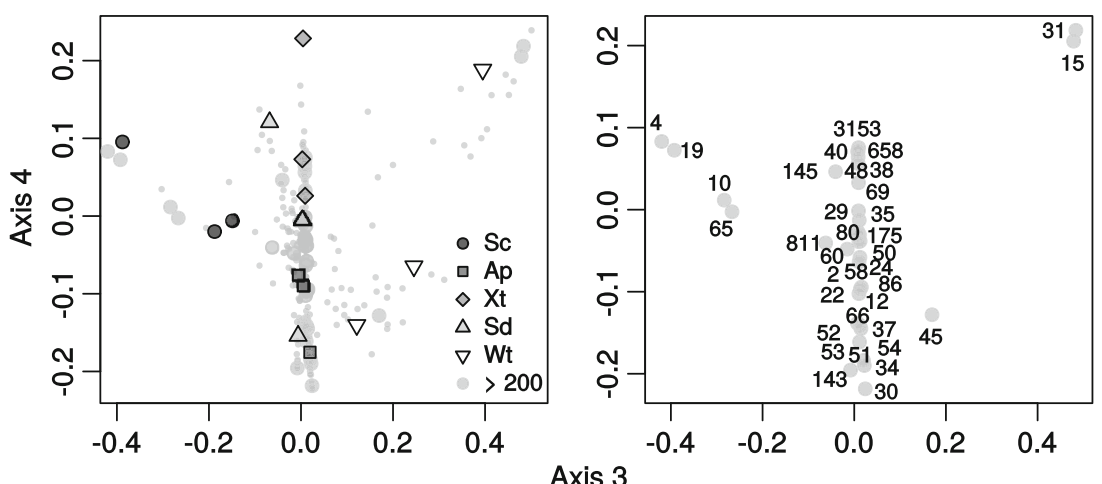

Fig. 7 Ordination showing the third and fourth axes of the PCO analysis. a. Symbols represent samples from $S$. carteri $(\mathrm{Sc})$, A. suberitoides (Ap),

$X$. testudinaria $(\mathrm{Xt})$, sediment $(\mathrm{Sd})$, and seawater $(\mathrm{Wt}) . \mathrm{b}$. Ordination

showing only the most abundant OTUs. Numbers represent dominant ( $\geq 200$ sequence reads) OTUs referred to in Table 1 . Small circles represent OTUs $<200$ sequence reads

Red Sea (Fig. 7 and Table 1). OTUs 15 and 31, which were associated with seawater samples, were related to organisms previously obtained from shrimp pond and seawater samples in China. The fourth axis mainly separated samples of A. suberitoides and $X$. testudinaria.

In general, most of the sponge OTUs analysed here were either detected in more than one sponge biotope or were closely related to bacterial phylotypes associated with different sponge host species (Table 1 and Fig. 8). For example, A. suberitoides and $X$. testudinaria shared dominant bacterial symbionts (ApXt in Table 1) closely related to bacterial phylotypes previously identified in a range of sponge hosts (Xestospongia muta, Aplysina cauliformis, Ircinia spp., Rhopaloeides odorabile, Astrosclera willeyana, and Vaceletia crypta) in different geographical locations. Most abundant sponge OTUs were closely related to sponge bacterial symbionts from other studies from different sponge species. However, a few abundant OTUs, selectively enriched in $X$. testudinaria or $S$. carteri (OTUs 4, 10, 48, 65, and 658), may represent sponge species specific associations.

\section{Discussion}

In line with previous studies (Cleary et al. 2015; de Voogd et al. 2015), the sediment biotope proved to be the richest. OTUs in sediment were mainly assigned to the Proteobacteria, but there were substantial numbers of OTUs assigned to other taxa including Actinobacteria, Bacteroidetes, and Acidobacteria, among others. OTUs assigned to the proteobacterial order Desulfobacterales were also restricted to sediment. The Desulfobacterales order consists of anaerobic bacteria known to use sulphate as terminal electron acceptor in order to oxidate $\mathrm{H}_{2}$ and a wide range of organic compounds. They also have been shown to play an important role in degrading organic contaminants and appear to be sensitive to predicted shifts in ocean $\mathrm{pH}$ (Coelho et al. 2015; Muyzer and Stams 2008; Zhou et al. 2011).

Proteobacteria also proved to be the most abundant phylum in S. carteri and in two of the three seawater and A. suberitoides samples. In contrast, Chloroflexi and Actinobacteria were more prevalent in samples of $X$. testudinaria. The dominance of Proteobacteria in $S$. carteri is in line with previous studies of this species in a different region within Indonesia (Cleary et al. 2015) and of the closely related S. massa in the Jakarta BayThousand Islands reef complex (de Voogd et al. 2015). LMA sponges, such as $S$. carteri, have been shown to host bacterial communities with limited phylum-level diversity when compared to HMA species. They are also known to filter large volumes of water, which can explain the presence of large numbers of OTUs found in water and the higher similarity between seawater and $S$. carteri bacterial communities (Giles et al. 2013; Weisz et al. 2008).

The prevalence of Chloroflexi in X. testudinaria in the present study agrees with previous studies of the species in other regions including the Red Sea, Celebes Sea, and Great Barrier Reef where Acidobacteria, Actinobacteria and particularly Chloroflexi were the most abundant phyla in terms of OTUs and sequences (Lee et al. 2011; Montalvo et al. 2014; Montalvo and Hill 2011). It, however, contrasts with two of our previous studies (Cleary et al. 2015; de Voogd et al. 2015) where Proteobacteria were more abundant in terms of OTUs and sequence reads although both of these studies also contained a large number of OTUs assigned to the Chloroflexi. Previous studies have also identified Chloroflexi as a consistent component of the bacterial communities of HMA sponges (Gloeckner et al. 2014; Schmitt et al. 2011).

In the present study, OTUs assigned to the Chloroflexi were mainly assigned to the orders SAR202 and Anaerolineae. Members of the SAR202 have been found to be relatively abundant in bathypelagic waters (Varela et al. 2008). Anaerolinae members have been found in a wide range of habitats from artic permafrost to tropical marine sediment and the mammalian gastrointestinal tract (Campbell et al. 2014; Hug et al. 2013). Campbell et al. (2014) proposed that Anaerolinae in humans occupy an ecological niche where they 
100_29_ApXt_SAR202

Uncultured Chloroflexi - sponge_Xestospongia testudinaria_GI:350627603 35_ApXt*_SAR202

100 Uncultured bacterium - sponge_Astrosclera willeyana Gl:678605861 -34_ApXt*_mle1-48

100 Uncultured Chloroflexi - sponge_Aplysina cauliformis_Gl:526300040 69_ApXt*_SAR202

100 Uncultured Chloroflexi - sponge_Xestospongia testudinaria_Gl:350627635

175_ApXt*_SAR202

100 19_Sc_Nitrospirales

Uncultured Nitrospira - sponge_Axinella corrugata_Gl:127692649

100 37_ApXt*_Caldilineales

Uncultured Chloroflexi - sponge_Aplysina cauliformis_Gl:526299835

100 658_Xt* Caldilineales

99 Uncultured Chloroflexi - sponge_Xestospongia testudinaria_GI:350627590 Uncultured Synechococcus - bacterioplankton_GI:28557443

2_Gen_Synechococcales

100 811_ScWt_Synechococcales

${ }_{67}$ Synechococcus sp. UW122 - marine autotrophic picoplankton_Gl:393716953

100 4_Sc*_NB1-j

Uncultured bacterium - sponge_Stylissa carteri_Gl:407912992

60 ApXt_EC214

${ }_{100}$ Uncultured Desulfovibrionales - sponge_Xestospongia testudinaria_GI:315020327 94-40_Xt* Gemm-4

100 Uncultured Gemmatimonadetes - sponge Xestospongia muta GI:350627485

54_Ap*_Gemm-4

${ }_{92}$ Uncultured bacterium - sponge Hyrtios erectus GI:290575663

_86_ApXt_Entotheonellales

100 Uncultured bacterium - sponge_Ircinia spp_Gl:451354009

69-3153_ApXt_Acidimicrobiales

${ }_{100}$ Uncultured actinobacterium - sponge_Xestospongia muta_GI:226425311

12_ApXt*_Acidimicrobiales

${ }_{100}$ 24_ApXt*_Acidimicrobiales

Uncultured actinobacterium - sponge_Aplysina cauliformis_Gl:526299843

58_ApXt*_Acidimicrobiales

100 Uncultured Acidimicrobidae - sponge Xestospongia testudinaria GI:350627578 100 38_ApXt_BPC015

Uncultured Acidobacteria - sponge Xestospongia testudinaria GI:226443728

80_ApXt_Syntrophobacterales

100 Uncultured bacterium - sponge_Ircinia spp_Gl:451353961

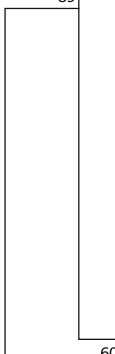

100-53_ApXt*_Rhodospirillales

Uncultured bacterium - sponge_Astrosclera willeyana_GI:678605876

66 ApXt_Rhodospirillales

100 Uncultured bacterium - sponge_Astrosclera willeyana_GI:678605851 145 Sd Rhodobacterales 30_Ap_Alphaproteobacteria

100 Uncultured Rhodovulum - sponge_larvae of Rhopaloeides odorabile_Gl:345330451 51_ApXt*_Rhodospirillales

100 Uncultured bacterium - sponge_Ircinia spp_Gl:451354037

100 50_ApXt_Chromatiales

Uncultured bacterium - sponge_Ircinia spp_GI:451353954

${ }^{100}$ - Uncultured bacterium - sponge_Stylissa carteri_Gl:407912993

665_Sc*_Thiohalorhabdales

Uncultured bacterium - sponge Stylissa carteri Gl:407913000

98 100 Uncultured bacterium

100 Uncultured bacterium - sponge Xestospongia testudinaria GI:350627620

48_Xt*_Thiotrichales

Uncultured bacterium - spponge_Vaceletia crypta_GI:511630206

100 22_ApXt_Thiotrichales 143_Sd*_Thiotrichales

Uncultured bacterium - sponge_Astrosclera willeyana_Gl:678605848

100 52_ApXt_Chromatiales

$100[15$ Wt_Flavobacteriales

45 ScWt Rickettsiales

100 Pelagibacter ubique HTCC1002 - ubiquitous marine bacterioplankton_GI:22297187

$$
\longmapsto 0.05
$$

Fig. 8 Phylogenetic tree of the bacterial 16S rRNA gene sequences recovered from $S$. carteri, A. suberitoides, $X$. testudinaria, sediment, and seawater from the Misool coral reef system. Bootstrap values lower than $50 \%$ were omitted. The number of each OTU is indicated as are GenInfo sequence identifiers of sequences obtained using BLAST 
scavenge material from lysed bacterial cells and human tissue. In sponges, they may occupy a similar niche whereby they exploit the high loss of sponge biomass due to rapid sponge cell turnover (de Goeij et al. 2013).

Seawater samples mainly consisted of OTUs assigned to Proteobacteria, Bacteroidetes, and Cyanobacteria. Alphaproteobacteria were most abundant in seawater samples and mainly consisted of OTUs assigned to the orders Rickettsiales and Rhodobacterales. The order Flavobacteriales was also mainly found in seawater samples. This result follows numerous studies that have found a prevalence of Proteobacteria (mainly Alphaproteobacteria) and Bacteroidetes in the bacterioplankton (Glöckner et al. 1999).

$S$. carteri and seawater samples clustered together in the PCO ordination as did A. suberitoides and $X$. testudinaria samples. With respect to $S$. carteri and seawater, this confirms previous studies highlighting the similarity of LMA sponges and seawater (Giles et al. 2013; Weisz et al. 2008). However, it should be noted that, although similar, samples of $S$. carteri were still distinct from seawater samples as seen in the ordination of the third and fourth axes. Stylissa carteri also contained highly abundant OTUs that were either much more abundant in or restricted to $S$. carteri. These OTUs were also closely related to organisms previously obtained from S. carteri samples in Saudi Arabia or Axinella, which were previously placed in the same order (Halichondrida).

The similarity in bacterial symbiont composition between A. suberitoides and $X$. testudinaria is interesting. These species are otherwise very different, e.g., their outer morphology, skeletal architecture and phylogenetic relationship. For instance, A. suberitoides has a massive to lobate growth form, whereas $X$. testudinaria is barrel shaped. However, the skeleton of both sponge species, is composed of high densities of silicious spicules, albeit of different size dimensions and morphologies. The similarity in the composition of their bacterial symbionts is thus in line with the theory that the internal sponge morphology is an important determinant whether a sponge hosts a HMA- or LMA-type bacterial community (Gloeckner et al. 2014; Vacelet and Donadey 1977; Weisz et al. 2008).

This is, to the best of our knowledge, the first study of the bacterial community of $A$. suberitoides, a relatively abundant, widespread and easily recognisable sponge species. Recently, the higher classification of sponges has been altered and some sponge orders have been abandoned (Morrow and Cárdenas 2015). Previously, the genus Aaptos (order Suberitida, family Suberitidae) was place within the order Hadromerida, which contained HMA sponges, such as Spheciospongia vesparium (currently order Clionaida; family Clionaidae) and LMA sponges such as Suberites domuncula (currently order Suberitida, family Suberitidae) and Suberites diversicolor (Cleary et al. 2013). Gloeckner et al. (2014) previously showed that although certain sponge taxa such as the orders
Agelasida and Verongida only consisted of HMA species and the Poecilosclerida of LMA species, other taxa such as the Haplosclerida, Homoscleromorpha, and Dictyoceratida included both LMA and HMA species.

In conclusion, the present study confirms that sponges harbour microbial communities that are distinct from communities in sediment and the surrounding seawater. This finding extends to LMA sponges as demonstrated by $S$. carteri in this study. Although the bacterial communities of $S$. carteri and seawater were similar, they were still distinct with $S$. carteri hosting a small number of highly abundant OTUs including OTUs restricted to this sponge. Our study also showed that the hitherto unknown bacterial community of $A$. suberitoides is very similar to the known HMA sponge $X$. testudinaria providing evidence that $A$. suberitoides might also be a HMA sponge. Although both $A$. suberitoides and $X$. testudinaria shared numerous OTUs, they also hosted what may be species-specific OTUs.

Acknowledgements Funding for the present study was provided by grants to the projects LESS CORAL (PTDC/AAC-AMB/115304/2009), Ecotech-Sponge (PTDC/BIA-MIC/6473/2014 - POCI-01-0145-FEDER016531) and to CESAM (UID/AMB/50017 - POCI-01-0145-FEDER007638) by FCT/MEC through national funds and co-funding by FEDER within the PT2020 Partnership Agreement and Compete 2020. The Netherlands Organisation for Scientific Research provided funding to LEB through the grant RUBICON \#825.12.007 and VENI\#863.14.020. We are grateful for the support in the field by Misool Eco Resort, Andy Miners, Dadi, Christiaan de Leeuw, and The Nature Conservancy.

\section{Compliance with ethical standards}

Funding Funding for the present study was provided by grants to the projects LESS CORAL (PTDC/AAC-AMB/115304/2009), EcotechSponge (PTDC/BIA-MIC/6473/2014 - POCI-01-0145-FEDER-016531) and to CESAM (UID/AMB/50017 - POCI-01-0145-FEDER-007638) by FCT/MEC through national funds and co-funding by FEDER within the PT2020 Partnership Agreement and Compete 2020. The Netherlands Organisation for Scientific Research provided funding to LEB through the grant RUBICON \#825.12.007 and VENI\#863.14.020. Fieldwork was supported by Ristek and LIPI, Indonesia.

Conflict of interest The authors declare that they have no conflicts of interest.

\section{References}

Akiyama T, Takada K, Oikawa T, Matsuura N, Ise Y, Okada S, Matsunaga S (2013) Stimulators of adipogenesis from the marine sponge Xestospongia testudinaria. Tetrahedron 69:6560-6564. doi: 10.1016/j.tet.2013.06.007

Allen GR (2008) Conservation hotspots of biodiversity and endemism for indo-Pacific coral reef fishes. Aquat Conserv Mar Freshwat Ecosyst 18:541-556

Allen GR, Erdmann MV (2009) Reef fishes of the bird's head peninsula, West Papua, Indonesia. Check List 5:587-628 
Aoki S, Kong D, Suna H, Sowa Y, Sakai T, Setiawan A, Kobayashi M (2006) Aaptamine, a spongean alkaloid, activates p21 promoter in a p53-independent manner. Biochem Bioph Res Commun 342:101106. doi:10.1016/j.bbrc.2006.01.119

Becking LE, de Leeuw C, Vogler C (2014) Newly discovered "jellyfish lakes" in Misool, Raja Ampat, Papua, Indonesia. Mar Biodivers 45: 597-598

Bellwood DR, Hughes TP, Folke C, Nyström M (2004) Confronting the coral reef crisis. Nature 429:827-833

Borchiellini C, Manuel M, Alivon E, Boury-Esnault N, Vacelet J, Le Parco Y (2001) Sponge paraphyly and the origin of Metazoa. J Evol Biol 14:171-179. doi:10.1046/j.1420-9101.2001.00244.x

Bruno JF, Selig ER (2007) Regional decline of coral cover in the indoPacific: timing, extent, and subregional comparisons. PLoS One 2: e711

Campbell AG, Schwientek P, Vishnivetskaya T, Woyke T, Levy S, Beall CJ, Griffen A, Leys E, Podar M (2014) Diversity and genomic insights into the uncultured Chloroflexi from the human microbiota. Environ Microbiol 16:2635-2643. doi:10.1111/1462-2920.12461

Capone DG, Dunham SE, Horrigan SG, Duguay LE (1992) Microbial nitrogen transformations in unconsolidated coral reef sediments. Mar Ecol Prog Ser 80:75-88

Cleary DFR (2003) An examination of scale of assessment, logging and ENSO-induced fires on butterfly diversity in Borneo. Oecologia 135:313-321. doi:10.1007/s00442-003-1188-5

Cleary DFR, Becking LE, de Voogd NJ, Pires ACC, Polónia ARM, Egas C, Gomes NCM (2013) Habitat- and host-related variation in sponge bacterial symbiont communities in Indonesian waters. FEMS Microbiol Ecol 85:465-482. doi:10.1111/1574-6941.12135

Cleary DFR, de Voogd NJ, Polónia ARM, Freitas R, Gomes NCM (2015) Composition and predictive functional analysis of bacterial communities in seawater, sediment and sponges in an Indonesian coral reef environment. Microb Ecol 70:889-903

Coelho FJ, Cleary DFR, Rocha RJ, Calado R, Castanheira JM, Rocha et al (2015) Unraveling the interactive effects of climate change and oil contamination on laboratory-simulated estuarine benthic communities. Glob Chang Biol 21:1871-1886

De'ath G, Fabricius KE, Sweatman H, Puotinen M (2012) The 27-year decline of coral cover on the Great Barrier reef and its causes. Proc Natl Acad Sci U S A 109:17995-17999

de Goeij JM, van Oevelen D, Vermeij MJ, Osinga R, Middelburg JJ, de Goeij AF, Admiraal W (2013) Surviving in a marine desert: the sponge loop retains resources within coral reefs. Science 342:108110. doi:10.1126/science. 1241981

de Voogd NJ, Cleary DFR (2008) An analysis of sponge diversity and distribution at three taxonomic levels in the Thousand Islands/Jakarta Bay reef complex, West-java, Indonesia. Mar Ecol 29:205-215

de Voogd NJ, Cleary DFR (2009) Variation in sponge composition among Singapore reefs. Raffles B Zool Suppl 22:59-67

de Voogd NJ, Cleary DFR, Hoeksema BW, Noor A, van Soest RWM (2006) Sponge beta diversity in the Spermonde archipelago, SW Sulawesi, Indonesia. Mar Ecol Prog Ser 309:131-142. doi:10. 3354/meps309131

de Voogd NJ, Cleary DFR, Polónia ARM, Gomes NCM (2015) Bacterial community composition and predicted functional ecology of sponges, sediment and seawater from the thousand islands reef complex, West java, Indonesia. FEMS Microbiol Ecol 91:1-12. doi:10. 1093/femsec/fiv019

Ebada SS, Linh MH, Longeon A, de Voogd NJ, Durieu E, Meijer L, Bourguet-Kondracki ML, Singab AN, Müller WE, Proksch P (2015) Dispacamide E and other bioactive bromopyrrole alkaloids from two Indonesian marine sponges of the genus Stylissa. Nat Prod Res 29:231-238. doi:10.1080/14786419.2014.947496

Edgar RC (2013) UPARSE: highly accurate OTU sequences from microbial amplicon reads. Nat Methods 10:996-998
Edgar R, Haas B, Clemente J, Quince C, Knight R (2011) UCHIME improves sensitivity and speed of chimera detection. Bioinformatics 27:2194-2200

Faulkner DJ (2002) Marine natural products. Nat Prod Rep 19:1-48. doi: $10.1039 / \mathrm{b} 009029 \mathrm{~h}$

Flatt PM, Gautschi JT, Thacker RW, Musafija-Girt M, Crews P, Gerwick WH (2005) Identification of the cellular site of polychlorinated peptide biosynthesis in the marine sponge Dysidea (Lamellodysidea) herbacea and symbiotic cyanobacterium Oscillatoria spongeliae by CARD-FISH analysis. Mar Biol 147:761-774. doi:10.1007/ s00227-005-1614-9

Freeman CJ, Thacker RW (2011) Complex interactions between marine sponges and their symbiotic microbial communities. Limnol Oceanogr 56:1577-1586. doi:10.4319/1o.2011.56.5.1577

Giles C, Kamke J, Moitinho-Silva L, Taylor MW, Hentschel U, Ravasi T, Schmitt S (2013) Bacterial community profiles in low microbial abundance sponges. FEMS Microbiol Ecol 83:232-241

Giles EC, Saenz-Agudelo P, Hussey NE, Ravasi T, Berumen ML (2015) Exploring seascape genetics and kinship in the reef sponge Stylissa carteri in the Red Sea. Ecol Evol 5:2487-2502. doi:10.1002/ece3. 1511

Glöckner FO, Fuchs BM, Amann R (1999) Bacterioplankton compositions of lakes and oceans: a first comparison based on fluorescence in situ hybridization. Appl Environ Microbiol 65:3721-3726

Gloeckner V, Wehrl M, Moitinho-Silva L, Gernert C, Schupp P, Pawlik JR et al (2014) The HMA-LMA dichotomy revisited: an electron microscopical survey of 56 sponge species. Biol Bull 227:78-88

Gomes NCM, Heuer H, Schönfeld J, Costa RS, Mendonça-Hagler LCS et al (2001) Bacterial diversity of the rhisosphere of maize (Zea mays) grown in tropical soil studied by temperature gradient gel electrophoresis. Plant Soil 232:167-180. doi:10.1023/A: 1010350406708

Gomes NCM, Cleary DFR, Pinto FN, Egas C, Almeida A, Cunha A, Mendonça-Hagler LCS, Smalla K (2010) Taking root: enduring effect of rhisosphere bacterial colonization in mangroves. PLoS One 5:e14065-a

Grantham HS, Agostini VN, Wilson J, Mangubhai S, Hidayat N, Muljadi A et al (2013) A comparison of zoning analyses to inform the planning of a marine protected area network in Raja Ampat. Indones Mar Policy 38:184-194

Hentschel U, Fieseler L, Wehrl M, Gernert C, Steinert M, Hacker J, Horn M (2003) Microbial diversity of marine sponges. In: Muller WE (ed) Sponges (Porifera). Springer-Verlag, Heidelberg, pp 59-88

Hentschel U, Usher KM, Taylor MW (2006) Marine sponges as microbial fermenters. FEMS Microbiol Ecol 55:167-177

Huang YM, de Voogd NJ, Cleary DFR, Li TH, Mok HK, Ueng JP (2016) Biodiversity pattern of Subtidal sponges (Porifera: Demospongiae) in the Penghu archipelago (Pescadores), Taiwan. J Mar Biol Assoc UK 96:417-427. doi:10.1017/S002531541500017X

Hug LA, Castelle CJ, Wrighton KC, Thomas BC, Sharon I, Frischkorn KR, Williams KH, Tringe SG. Banfield JF (2013) Community genomic analyses constrain the distribution of metabolic traits across the Chloroflexi phylum and indicate roles in sediment carbon cycling. Microbiome 1:1 - 22. doi: 10.1186/2049-2618-1-22.

Jin M, Zhao W, Zhang Y, Kobayashi M, Duan H, Kong D (2011) Antiproliferative effect of aaptamine on human chronic myeloid leukemia K562 cells. Int J Mol Sci 12:7352-7359. doi:10.3390/ ijms 12117352

Kamke J, Taylor MW, Schmitt S (2010) Activity profiles for marine sponge-associated bacteria obtained by $16 \mathrm{~S}$ rRNA vs $16 \mathrm{~S}$ rRNA gene comparisons. ISME J 4:498-508. doi:10.1038/ismej.2009.143

Larghi EL, Obrist BV, Kaufman TS (2008) A formal total synthesis of the marine alkaloid aaptamine. Tetrahedron 64:5236-5245. doi:10. 1016/j.tet.2008.03.036

Lee OO, Wang Y, Yang J, Lafi FF, Al-Suwailem A, Qian PY (2011) Pyrosequencing reveals highly diverse and species-specific 
microbial communities in sponges from the Red Sea. ISME J 5:650 664. doi:10.1038/ismej.2010.165

Legendre P, Gallagher E (2001) Ecologically meaningful transformations for ordination of species data. Oecologia 129:271-280. doi:10.1007/ s004420100716

Li CW, Chen JY, Hua TE (1998) Precambrian sponges with cellular structures. Science 279:879-882

Liang LF, Wang T, Cai YS, He WF, Sun P, Li YF, Huang Q, TaglialatelaScafati O, Wang HY, Guo YW (2014) Brominated polyunsaturated lipids from the Chinese sponge Xestospongia testudinaria as a new class of pancreatic lipase inhibitors. Eur J Med Chem 79:290-297. doi:10.1016/j.ejmech.2014.04.003

Liu C, Tang X, Li P, Li G (2012) Suberitine A-D, four new cytotoxic dimeric aaptamine alkaloids from the marine sponge Aaptos suberitoides. Org Lett 14:1994-1997. doi:10.1021/ol3004589

Mangubhai S, Erdmann MV, Wilson JR, Huffard CL, Ballamu F, Hidayat NI, Hitipeuw C, Lazuardi ME et al (2012) Papuan Bird's head seascape: emerging threats and challenges in the global center of marine biodiversity. Mar Pollut Bull 64:2279-2295

McMurray SE, Blum JE, Pawlik JR (2008) Redwood of the reef: growth and age of the giant barrel sponge Xestospongia muta in the Florida keys. Mar Biol 155:159-171

Moberg F, Folke C (1999) Ecological goods and services of coral reef ecosystems. Ecol Econ 29:215-233

Moitinho-Silva L, Bayer K, Cannistraci CV, Giles EC, Ryu T, Seridi L, Ravasi T, Hentschel U (2014) Specificity and transcriptional activity of microbiota associated with low and high microbial abundance sponges from the Red Sea. Mol Ecol 23:1348-1363. doi:10.1111/ mec. 12365

Montalvo NF, Hill RT (2011) Sponge-associated bacteria are strictly maintained in two closely related but geographically distant sponge hosts. Appl Environ Microbiol 77:7207-7216. doi:10.1128/AEM. 05285-11

Montalvo NF, Davis J, Vicente J, Pittiglio R, Ravel J, Hill RT (2014) Integration of culture-based and molecular analysis of a complex sponge-associated bacterial community. PLoS One 9:e90517

Morrow C, Cárdenas P (2015) Proposal for a revised classification of the Demospongiae (Porifera). Front Zool 12:1-7

Muyzer G, Stams AJM (2008) The ecology and biotechnology of sulphate-reducing bacteria. Nat Rev Microbiol 6:441-454

Oksanen J, Kindt R, Legendre P, O'Hara B, Simpson GL, Solymos P, Wagner H (2009) Vegan: community ecology package. R Packag Vers 1:15-14 Retrieved from http://www.cran.r-project.org/ package $=$ vegan

Pandolfi JM, Bradbury RH, Sala E, Hughes TP, Bjorndal KA, Cooke RG, McArdle D, McClenachan L, Newman MJ, Paredes G, Warner RR, Jackson JBC (2003) Global trajectories of the long-term decline of coral reef ecosystems. Science 301:955-958

Pham NB, Butler MS, Hooper JNA, Moni RW, Quinn RJ (1999) Isolation of xestosterol esters of brominated acetylenic fatty acids from the marine sponge Xestospongia testudinaria. J Nat Prod 62:1439-1442

Pham CD, Hartmann R, Müller WEG, de Voogd NJ, Lai D, Proksch P (2013) Aaptamine derivatives from the indonesian sponge Aaptos suberitoides. J Nat Prod 76:103-106. doi:10.1021/np300794b

Polónia ARM, Cleary DFR, Freitas R, de Voogd NJ, Gomes NCM (2014) The putative functional ecology and distribution of archaeal communities in sponges, sediment and seawater in a coral reef environment. Mol Ecol 24:409-423. doi:10.1111/mec.13024

Prentice ML, Hope GS (2007) Climate of Papua. In: Marshall AJ, Beehler BM (eds) The ecology of Papua: part one. Periplus, Singapore, pp 177-196
Roberts CM, McClean CJ, Veron JE, Hawkins JP, Allen GR, McAllister DE et al (2002) Marine biodiversity hotspots and conservation priorities for tropical reefs. Science 295:1280-1284

Rohde S, Gochfeld D, Ankisetty S, Avula B, Schupp P, Slattery M (2012) Spatial variability in secondary metabolites of the indo-pacific sponge Stylissa massa. J Chem Ecol 38:463-475. doi:10.1007/ s10886-012-0124-8

Rützler K (2004) Sponges on coral reefs: a community shaped by competitive cooperation. Bollettino dei Musei e degli Instituti Biologici dell'Universita Di Genova 68:85-148

Schlappy ML, Schottner SI, Lavik G, Kuypers MM, de Beer D, Hoffmann F (2010) Evidence of nitrification and denitrification in high and low microbial abundance sponges. Mar Biol 157:593-602

Schmitt S, Deines P, Behman F, Wagner M, Taylor MW (2011) Chloroflexi bacteria are more diverse, abundant, and similar in high than in low microbial abundance sponges. FEMS Microbiol Ecol 78:497-510

van Soest RWM, Boury-Esnault N, Vacelet J, Dohrmann M, Erpenbeck D, de Voogd NJ, Santodomingo N, Vanhoorne B, Kelly M, Hooper JNA (2012) Global diversity of sponges (Porifera). PLoS One 7:1-23

Swierts T, Peijnenburg KTCA, de Leeuw C, Cleary DFR, Setiawan E, Wörheide G, Erpenbeck D, de Voogd NJ (2013) Lock, stock and two different barrels: comparing the genetic composition of morphotypes of the indo-Pacific sponge Xestospongia testudinaria. PLoS One 8:1-12. doi:10.1371/journal.pone.0074396

Tamura K, Stecher G, Peterson D, Filipski A, Kumar S (2013) MEGA6: Molecular evolutionary genetics analysis version 6.0. Mol Biol Evol 30:2725-2729

Taylor MW, Radax R, Steger D, Wagner M (2007) Sponge-associated microorganisms: evolution, ecology, and biotechnological potential. Microbiol Mol Biol Rev 71:295-347. doi:10.1128/MMBR.00040-06

Tsukamoto S, Yamanokuchi R, Yoshitomi M, Sato K, Ikeda T, Rotinsulu $\mathrm{H}$, Mangindaan REP, de Voogd NJ, van Soest RWM, Yokosawa H (2010) Aaptamine, an alkaloid from the sponge Aaptos suberitoides, functions as a proteasome inhibitor. Bioorg Med Chem Lett 20: 3341-3343. doi:10.1016/j.bmcl.2010.04.029

Vacelet J, Donadey C (1977) Electron microscope study of the association between some sponges and bacteria. J Exp Mar Biol Ecol 30:301-314

Varela MM, van Aken HM, Herndl GJ (2008) Abundance and activity of Chloroflexi-type SAR202 bacterioplankton in the meso- and bathypelagic waters of the (sub)tropical Atlantic. Environ Microbiol 10: 1903-1911. doi:10.1111/j.1462-2920.2008.01627.x

Vaz-Moreira I, Egas C, Nunes OC, Manaia CM (2011) Culturedependent and culture-independent diversity surveys target different bacteria: a case study in a freshwater sample. Antonie Van Leeuwenhoek 100:245-257

Weisz JB, Lindquist N, Martens CS (2008) Do associated microbial abundances impact marine demosponge pumping rates and tissue densities. Oecologia 155:367-376. doi:10.1007/s00442-007-0910-0

Yu Y, Lee C, Kim J, Hwang S (2005) Group-specific primer and probe sets to detect methanogenic communities using quantitative realtime polymerase chain reaction. Biotechnol Bioeng 89:670-679

Zhang Z, Schwartz S, Wagner L, Miller W (2000) A greedy algorithm for aligning DNA sequences. J Comput Biol 7:203-214

Zhou J, He Q, Hemme CL, Mukhopadhyay A, Hillesland K, Zhou A, He Z, Van Nostrand JD, Hazen TC, Stahl DA, Wall JD, Arkin AP (2011) How sulphate-reducing microorganisms cope with stress: lessons from systems biology. Nat Rev Microbiol 9:452-466. doi: $10.1038 /$ nrmicro 2575 